\title{
Regulation of Adrenal Ornithine Decarboxylase by Adrenocorticotropic Hormone and Cyclic AMP
}

\author{
R. Richman, C. Dobbins, S. Voina, L. Underwood, D. Mahaffee, \\ H. J. Gitelman, J. Van WyK, and R. L. Ney \\ From the Departments of Medicine, Pediatrics, and Physiology, University of \\ North Carolina, Chapel Hill, North Carolina 27514
}

A B S T R A C T Adrenal ornithine decarboxylase activity was stimulated in a dose-related manner after administration of ACTH or dibutyryl ( ${ }^{6} \mathrm{~N}-2^{\prime}-O$-dibutyryl) cyclic AMP to hypophysectomized rats. Little effect was observed for $2 \mathrm{~h}$, but striking increases in enzyme activity were observed $4 \mathrm{~h}$ after administration of these substances. Effects of ACTH and dibutyryl cyclic AMP were not secondary to stimulation of steroidogenesis, since hydrocortisone had no effect on adrenal ornithine decarboxylase although it did stimulate activity of the enzyme in the liver and kidney.

ACTH, given subcutaneously to hypophysectomized rats, induced striking increases in adrenal cyclic AMP levels within 15-30 min with a fall towards the base line in $1 \mathrm{~h}$. Increases in ornithine decarboxylase activity lag several hours after this endogenous cyclic AMP peak, in contrast to the stimulation of steroidogenesis by the nucleotide that requires only 2-3 min. After graded doses of ACTH, increases in adrenal cyclic AMP levels at $30 \mathrm{~min}$ were paralleled by proportional increases in adrenal ornithine decarboxylase activity $4 \mathrm{~h}$ after hormone treatment. Whereas maximal levels of adrenal steroidogenesis have been observed at tissue cyclic AMP levels of $6 \mathrm{nmol} / \mathrm{g}, \mathrm{ACTH}$ is capable of inducing increases in nucleotide levels up to 200 $\mathrm{nmol} / \mathrm{g}$ or more. These high tissue levels of cyclic AMP, although unnecessary for maximal steroidogenesis, appear to stimulate adrenal ornithine decarboxylase activity.

Several results in addition to the time lag in the stimulation of ornithine decarboxylase activity suggest a mechanism involving accumulation of the enzyme or some factor needed for its activity rather than direct activation of the enzyme by cyclic AMP. Thus, the addition of cyclic AMP directly to the ornithine decarboxylase assay mixture in vitro was without stimulatory

Received for publication 5 May 1972 and in revised form 27 March 1973. effect. In addition, actinonycin D or cycloheximide in doses sufficient to block adrenal RNA and protein synthesis, respectively inhibited the stimulation of ornithine decarboxylase activity by ACTH in vivo.

An adrenocortical cancer was found to maintain ornithine decarboxylase activity at very high levels, but did so at much lower cyclic AMP levels than those of ACTH-stimulated adrenals.

It is concluded that ACTH stimulates adrenal ornithine decarboxylase activity and that this effect may be mediated by cyclic AMP. However, cyclic AMP does not appear to be a determinant of the high level of enzyme activity found in adrenocortical cancer.

\section{INTRODUCTION}

Ornithine decarboxylase (L-ornithine carboxy-lyase, EC 4.1.1.17) catalyzes the formation of putrescine, which serves as a precursor for the polyamines spermidine and spermine $(1,2)$. The polyamines are widely distributed in nature, including bacterial and animal cells $(1,2)$. Although the exact physiological role of the polyamines is not known, attention has focused on their effects on RNA synthesis and metabolism (1-4). Ornithine decarboxylase activity as well as levels of putrescine and the polyamines increase in rapidly growing tissues, for example, certain organs of the chick embryo and the regenerating rat liver (3-5). Ornithine decarboxylase activity is also increased in certain tissues during hormone stimulation. For example, hydrocortisone and growth hormone stimulate enzyme activity in the liver, and testosterone stimulates activity in the prostate $(6-8)$.

ACTH stimulates the growth of the adrenal cortex. This growth-promoting effect is characterized by an initial cellular accumulation of RNA and protein, followed by DNA replication and cell division (9). In view of the potential significance of ornithine decar- 
boxylase activity in the control of RNA metabolism, we have carried out studies to determine if this activity in adrenal glands is regulated by ACTH. Furthermore, since cyclic ANIP serves as the intracellular mediator of the steroidogenic action of ACTH (10), we have also sought to determine if adrenal ornithine decarboxylase activity is subject to the influence of this nucleotide.

\section{METHODS}

Male Sprague-Dawley rats weighing $160-180 \mathrm{~g}$ were hypophysectomized by the transaural approach. Adrenal glands from groups of four to nine rats were pooled and used for the ornithine decarboxylase assay. In some experiments, a transplanted corticosterone-producing rat adrenocortical carcinoma was used (11). The tissues were homogenized at a concentration of $200 \mathrm{mg} / \mathrm{ml}$ in $0.05 \mathrm{M} \mathrm{Na}-\mathrm{K}$ phosphate buffer, $\mathrm{pH} 7.2$, containing $0.1 \mathrm{M}$ disodium EDTA at $4^{\circ} \mathrm{C}$. The homogenates were centrifuged at $20,000 \mathrm{~g}$ for 20 $\min$ at $4^{\circ} \mathrm{C}$, and the supernates immediately used for enzyme assay (5).

Ornithine decarboxylase activity was assayed, with minor modifications, by the method of Russell and Snyder (5). The reaction mixture contained $0.5 \mu \mathrm{Ci}$ of $\mathrm{DL}\left[1-{ }^{14} \mathrm{C}\right]$ ornithine hydrochloride (Amersham/Searle Corp. [Arlington Heights, Ill.], $17-37 \mathrm{mCi} / \mathrm{mmol}), 0.1 \mu \mathrm{mol}$ pyridoxal phosphate, $0.1-0.4 \mathrm{ml}$ of adrenal $20,000 \mathrm{~g}$ supernate, and buffer (described above) to make a final volume of $2 \mathrm{ml}$. Activity was usually measured at three different enzyme concentrations (for example $0.1,0.2$, and $0.4 \mathrm{ml}$ of added supernate) for each treatment group. Although $0.1 \mathrm{M}$ disodium EDTA was added to the reaction mixture based on earlier work (5), in the tissue supernates studied here, neither its presence nor that of added magnesium proved necessary for the maintenance of enzyme activity. We also tested ornithine decarboxylase activity at varying $\mathrm{pH}$ levels ranging from 6 to 8 and found that maximal activity occurred at a $\mathrm{pH}$ of 7.2, the level employed in each of the assays described here. Enzyme activity was linear over the $30 \mathrm{~min}$ time period used. The assay was carried out in 25-ml Erlenmeyer flasks sealed with a rubber stopper from which a polyethylene center well (Kontes Glass Co., Vineland, N. J.) was suspended. After incubation at $37^{\circ} \mathrm{C}$ for $30 \mathrm{~min}$ in a shaking waker bath, $1 \mathrm{ml}$ of $2 \mathrm{M}$ citric acid was injected into the reaction mixture through the rubber stopper to stop enzyme activity. $0.2 \mathrm{ml}$ of a $2: 1$ mixture of ethanolamine and 2-methoxyethanol was injected into the center well to trap liberated ${ }^{14} \mathrm{CO}_{2}$. After agitating at $37^{\circ} \mathrm{C}$ for an additional $30 \mathrm{~min}$, each well was removed and placed in a scintillation vial containing $2 \mathrm{ml}$ ethanol and $10 \mathrm{ml}$ scintillation fluid that had been made by adding $40 \mathrm{ml}$ Packard Permafluor $25 \mathrm{X}$ (Packard Instrument Co. Inc., Downers Grove, III.) and $960 \mathrm{ml}$ toluene.

Samples were counted in a Packard liquid scintillation spectrometer. Counting efficiency $(73 \pm 2 \%)$ was determined by the external standard method. Results are expressed as picomoles of $\mathrm{CO}_{2}$ liberated from ornithine per gram wet weight tissue from which the $20,000 g$ supernate was obtained per $30 \mathrm{~min}$ incubation. The amount of $\mathrm{CO}_{2}$ liberated from flasks containing heat-inactivated enzyme or no enzyme was subtracted from the value for all other samples. Comparable results were obtained using either blank sample. The calculation of picomoles of $\mathrm{CO}_{2}$ liberated as a result of ornithine decarboxylation was based on the specific activity of exogenous-labeled ornithine added to the assay mixture and was not corrected for further dilution of the isotope by endogenous ornithine. However, the endogenous adrenal content of ornithine was shown to he relatively con stant regardless of the treatment of animals from which glands were obtained (see Results).

The fact that ${ }^{14} \mathrm{CO}_{2}$ formation was in fact a reflection of ornithine decarboxylation was shown in experiments in which parallel tubes containing adrenal cancer 20,000 $g$ supernate were incubated with either $\left[1-{ }^{14} \mathrm{C}\right]$ ornithine or $\left[2-{ }^{14} \mathrm{C}\right]$ ornithine. Release of ${ }^{14} \mathrm{CO}_{2}$ was measured in the former as described above, and concomitant formation of putrescine was shown with the latter, isolating the labeled putrescine by paper electrophoresis as described by Raina (12). Furthermore, enzyme activity in adrenal or tumor supernates was inhibited when exogenous putrescine was added to the assay mixture, as has been described for prostatic ornithine decarboxylase (8).

To measure the adrenal content of ornithine, ${ }^{1}$ tissues were homogenized at a concentration of $20 \mathrm{mg} / \mathrm{ml}$ in sodium acetate buffer, $\mathrm{pH} 2.88$. The assay employed a Technicon AutoAnalyzer Modular system (Technicon Instruments Corp., Tarrytown, N. Y.) using a $140 \times 0.9 \mathrm{~cm}$ (ID) column packed with chromabeads resin, type $\mathrm{A}$. The ornithine peak was readily separable from that of other amino acids during a $23 \mathrm{~h}$ run and was quantitated from the area under the peak as previously described (13).

Tissue cyclic AMP concentrations were measured by a modification of the protein-binding method of Gilman (14) that employed a $\mathrm{pH} 3.5$ formate buffer for the incubation with protein kinase and kinase inhibitor in the final step of the assay.

ACTH in $8 \%$ gelatin $(40 \mathrm{U} / \mathrm{ml})$ was obtained from Armour Pharmaceutical Co. (Chicago, Ill.). Cyclic AMP was obtained from Sigma (Sigma Chemical Co., St. Louis, Mo.) and dibutyryl cyclic AMP from Boehringer Mannheim (Boehringer Mannheim Corp., New York). For in vivo administration, dibutyryl cyclic AMP was dissolved in $8 \%$ gelatin. Synthetic angiotension II was obtained from Ciba Pharmaceutical Co. (Summit, N. J.) and was dissolved in $8 \%$ gelatin for in vivo injection subcutaneously. Hydrocortisone hemisuccinate was purchased from The Upjohn Co., (Kalamazoo, Mich.), and cycloheximide was obtained from Sigma Chemical Co. Actinomycin D was a gift of Merck Sharp \& Dohme (West Point, Pa.). Tissue culture medium TC 199 with Hanks salts and bicarbonate was obtained from Grand Island Biological Co. (Grand Island, N. Y.).

\section{RESULTS}

Effects of ACTH and dibutyryl cyclic AMP on adrenal ornithine decarboxylase. Rats were hypophysectomized and immediately thereafter given ACTH subcutaneously. Groups of animals were sacrificed at varying time intervals after ACTH treatment, and the adrenals were removed for ornithine decarboxylase assay. Little effect was seen for $2 \mathrm{~h}$, but a marked increase in ornithine decarboxylase activity was seen $4 \mathrm{~h}$ after $20 \mathrm{U}$ ACTH (Fig. 1). Studies of the time course of the effect of ACTH on ornithine decarboxylase

${ }^{1}$ Ornithine assays were performed in the laboratory of Dr. George K. Summer, Department of Biochemistry, University of North Carolina. 


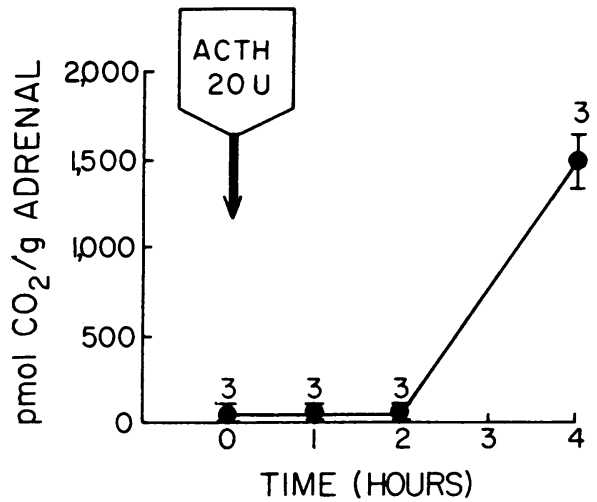

FiguRE 1 The time course of adrenal ornithine decarboxylase activity in hypophysectomized rats given $20 \mathrm{U}$ ACTH subcutaneously. Enzyme activity is expressed as picomoles $\mathrm{CO}$, liberated from ornithine per gram tissue. Each point represents the mean of three observations. The vertical bars indicate $1 \mathrm{SD}$.

activity were not extended beyond $4 \mathrm{~h}$, although experiments in other laboratories have suggested that even greater stimulatory effects may be observed at later time points (15). Varying doses of ACTH were tested, with adrenals removed $4 \mathrm{~h}$ after hormone treatment. $5 \mathrm{U}$ of ACTH resulted in an increase in enzyme activity. A maximal stimulatory effect was seen after the subcutaneous administration of $10 \mathrm{U}$ of $\mathrm{ACTH}$ (Fig. 2).

Since the presence of sulfhydryl-reducing agents has been utilized to maintain ornithine decarboxylase activity in other studies (16), experiments were performed to determine whether dithiothreitol would result in enhanced activity in adrenal supernates. In such an experiment, when dithiothreitol was present at a concentration of $1 \mathrm{mM}$ at the time of tissue homogenization, as well as all steps of the assay, ornithine decarboxylase activity in adrenals from hypophysectomized rats was $291 \pm 62 \mathrm{pmol} / \mathrm{g}$ (mean $\pm \mathrm{SEM}$ ) as compared with $246 \pm 47$ in the absence of the agent (three observations in each group). When adrenals were removed from hypophysectomized rats given ACTH $20 \mathrm{U}$ subcutaneously $4 \mathrm{~h}$ previously, activity in the presence of $1 \mathrm{mM}$ dithiothreitol was $2,765 \pm 132$, as compared with a level of $2,525 \pm 122$ in the absence of dithiothreitol. Even at a concentration of $5 \mathrm{mM}$, dithiothreitol failed to enhance ornithine decarboxylase activity in these supernates.

Since cyclic AMP mediates the effects of ACTH on adrenal steroidogenesis, we sought to determine whether the nucleotide might also mediate the observed effect of ACTH on adrenal ornithine decarboxylase activity. As an initial approach to this question, dibutyryl cyclic AMP was given subcutaneously to hy-

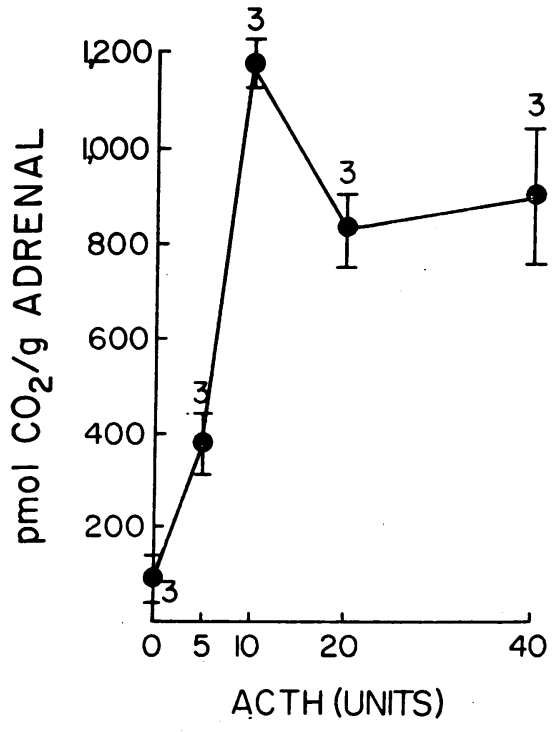

Figure 2 Effects of varying doses of subcutaneous ACTH on adrenal ornithine decarboxylase activity in hypophysectomized rats. Adrenals were excised $4 \mathrm{~h}$ after hormone administration. Enzyme activity is expressed as picomoles $\mathrm{CO}_{2}$ liberated from ornithine per gram tissue. Each point represents the mean of three observations. The vertical bars indicate $1 \mathrm{SD}$.

pophysectomized rats. Little effect was seen for $2 \mathrm{~h}$ after administration of $50 \mathrm{mg}$ of the nucleotide. A clear increase in ornithine decarboxylase activity occurred after $3 \mathrm{~h}$, and an even greater effect was observed at $4 \mathrm{~h}$ (Fig. 3). The effect of dibutyryl cyclic AMP on enzyme activity, tested $4 \mathrm{~h}$ after administration of the nucleotide, was dose-related (Fig. 4). Although the degree of stimulation varied from one experiment to another, $50 \mathrm{mg}$ dibutyryl cyclic AMP generally produced a greater increase in adrenal ornithine decarboxylase activity than that induced by a maximally stimulating dose of ACTH (Table I).

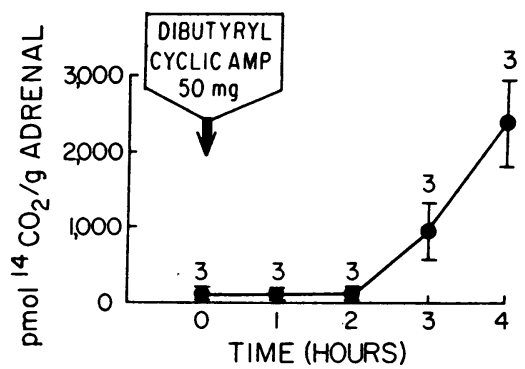

FIgURE 3 The time course of adrenal ornithine decarboxylase activity in hypophysectomized rats given $50 \mathrm{mg}$ dibutyryl cyclic AMP subcutaneously. Enzyme activity is expressed as picomoles ${ }^{14} \mathrm{CO}_{2}$ liberated from ornithine per gram tissue. Each point represents the mean of three observations. The vertical bars indicate $1 \mathrm{SD}$. 


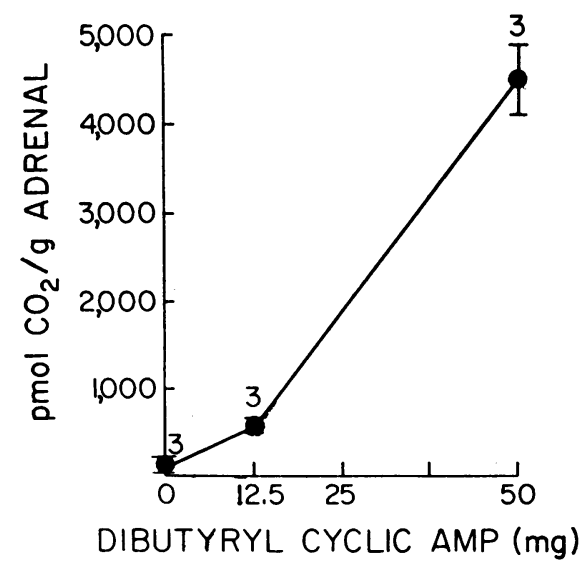

Figure 4 Ornithine decarboxylase activity in hypophysectomized rats given either no treatment or given 12.5 or 50 mg dibutyryl cyclic AMP subcutaneously. Adrenals were assayed $4 \mathrm{~h}$ after nucleotide administration. Enzyme activity is expressed as picomoles $\mathrm{CO}_{2}$ liberated from ornithine per gram tissue. Each point represents the mean of three observations. The vertical bars indicate $1 \mathrm{SD}$.

Since both ACTH and dibutyryl cyclic AMP stimulate adrenal steroidogenesis (17) and since corticosteroids are capable of increasing ornithine decarboxylase in other tissues (6-7), we considered the possibility that effects on adrenal ornithine decarboxylase were entirely secondary to increases in adrenal corticosteroids. This possibility was excluded in experiments in which hypophysectomized rats were given $5 \mathrm{mg}$ hydrocortisone, with no effect on adrenal enzyme activity (Table I). This dose of hydrocortisone stimulated hepatic ornithine decarboxylase (Table II), as previ-

\section{TABLE I}

Adrenal Ornithine Decarboxylase Activity in Hypophysectomized Rats $4 \mathrm{~h}$ after the Administration of Hormones or Dibutyryl Cyclic AMP

\begin{tabular}{lc}
\hline & Ornithine decarboxylase activity \\
\cline { 2 - 2 } \multicolumn{1}{c}{ Treatment } & Mean \pm SEM \\
\hline & $\begin{array}{c}\text { pmol } \mathrm{CO}_{2} \text { liberated from } \\
\text { ornithine/g tissue }\end{array}$ \\
None & $72 \pm 10(20)^{*}$ \\
ACTH, $20 \mathrm{U}$ & $1,324 \pm 139(12)$ \\
Dibutyryl cyclic AMP, 50 mg & $3,339 \pm 286(11)$ \\
Angiotensin II, $0.25 \mathrm{mg}$ & $39 \pm 21(3)$ \\
Hydrocortisone, $5 \mathrm{mg}$ & $9 \pm 2(3)$ \\
Na butyrate, $50 \mathrm{mg}$ & $13 \pm 11(3)$ \\
\hline
\end{tabular}

The ACTH, angiotensin II, dibutyryl cyclic AMP, and $\mathrm{Na}$ butyrate were given subcutaneously. Hydrocortisone was given intraperitoneally.

* The number of observations is shown in parentheses.
TABLE II

Effect of Dibutyryl Cyclic AMP and Hydrocortisone on Ornithine Decarboxylase Activity in Liver and Kidneys

\begin{tabular}{|c|c|c|}
\hline \multirow[b]{3}{*}{ Treatment } & \multicolumn{2}{|c|}{ Ornithine decarboxylase activity } \\
\hline & \multicolumn{2}{|c|}{ Mean \pm SEM } \\
\hline & Liver & Kidney \\
\hline & \multicolumn{2}{|c|}{ pmol $\mathrm{CO}_{2}$ liberated from ornithine/g tissue } \\
\hline \multicolumn{3}{|l|}{ Hypophysectomized rats } \\
\hline None & $177 \pm 155(3)^{*}$ & $983 \pm 114(3)$ \\
\hline $\begin{array}{l}\text { Dibutyryl cyclic } \\
\text { AMP, } 50 \mathrm{mg} \text {, s.c. }\end{array}$ & $689 \pm 40$ & $5,029 \pm 489(3)$ \\
\hline Hydrocortisone, $5 \mathrm{mg}$, & $1,466 \pm 242(3)$ & $40,799 \pm 2,749(3)$ \\
\hline \multicolumn{3}{|c|}{ Hypophysectomized and adrenalectomized rats } \\
\hline None & $312 \pm 294(3)$ & $151 \pm 63(3)$ \\
\hline $\begin{array}{l}\text { Dibutyryl cyclic } \\
\text { AMP, } 50 \mathrm{mg} \text {, s.c. }\end{array}$ & $369 \pm 170(3)$ & $233 \pm 96(3)$ \\
\hline
\end{tabular}

* The number of observations is shown in parentheses.

ously reported (7). Since angiotensin II stimulates aldosterone biosynthesis in the adrenal cortex, we also tested effects of the peptide on adrenal ornithine decarboxylase and observed no effect (Table I).

The levels of enzyme activity measured in adrenals from hypophysectomized rats, as well as in adrenals from hypophysectomized rats given ACTH or dibutyryl cyclic AMP, were linearly related to the quantities of tissue $20,000 \mathrm{~g}$ supernate added to the assay mixture (Fig. 5).

To rule out the possibility that alterations in substrate concentrations might play a role in the effects of ACTH and dibutyryl cyclic AMP on ornithine decarboxylase activity, levels of endogenous adrenal ornithine were measured and found to be similar in untreated rats and animals receiving these substances (Table III).

Relationship between endogenous adrenal cyclic AMP and ornithine decarboxylase activity. To further examine the possible role of cyclic AMP in the regulation of ornithine decarboxylase activity, endogenous adrenal cyclic AMP levels were measured in an effort to detect temporal and quantitative relationships with enzyme activity.

After the subcutaneous administration of ACTH, adrenal cyclic AMP levels reached high levels within $15 \mathrm{~min}$, remained elevated at $30 \mathrm{~min}$, and returned towards the base line in $1 \mathrm{~h}$. Fig. 6 shows results of an experiment in which adrenals were removed from hypophysectomized rats not given ACTH and from animals given ACTH subcutaneously $\frac{1}{2}, 1,2,3$, and $4 \mathrm{~h}$ before sacrifice. In contrast to the rapid stimulatory effects of ACTH on adrenal cyclic AMP levels, orni- 


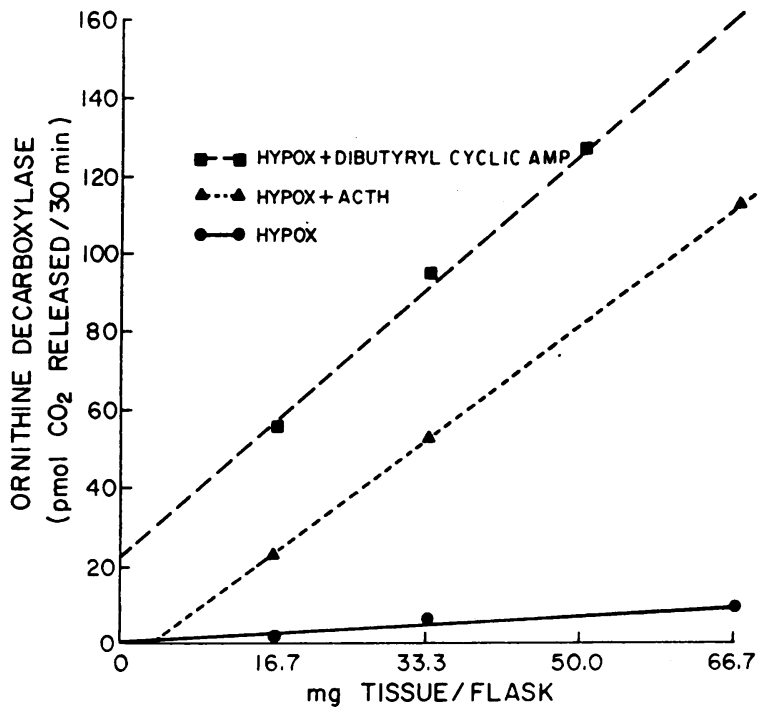

FIGURE 5 Relationship between the quantity of adrenal 20,$000 \mathrm{~g}$ supernate added to the ornithine decarboxylase assay mixture and enzyme activity. In this experiment adrenals were homogenized in buffer (see Methods) at a concentration of $167 \mathrm{mg} / \mathrm{my}$, and centrifuged at $20,000 \mathrm{~g}$. Varying quantities of supernates were added to the enzyme assay. The quantity of supernate is expressed as the milligrams wet tissue weight from which the supernate was derived. Adrenals were obtained from hypophysectomized rats either untreated or given ACTH $20 \mathrm{U}$ or dibutyryl cyclic AMP $50 \mathrm{mg}$ subcutaneously $4 \mathrm{~h}$ before sacrifice. Enzyme activity is expressed as picomoles $\mathrm{CO}_{2}$ liberated from ornithine during the $30 \mathrm{~min}$ assay. The term "hypox" refers to hypophysectomized animals.
TABLE III

Adrenal Ornithine Content in Hypophysectomized Rats, either Untreated or Given ACTH 20 U or Dibutyryl Cyclic AMP $50 \mathrm{mg} 4 \mathrm{~h}$ before Sacrifice

\begin{tabular}{lc}
\hline & $\begin{array}{c}\text { Adrenal } \\
\text { ornithine } \\
\text { content }\end{array}$ \\
\hline & $\mu m o l / g$ tissue \\
None & 6.8 \\
ACTH, 20 U & 4.0 \\
Dibutyryl cyclic AMP, $50 \mathrm{mg}$ & 7.0 \\
\hline
\end{tabular}

thine decarboxylase activity was unchanged for $2 \mathrm{~h}$ but was clearly increased by $4 \mathrm{~h}$. This lag contrasts with the rapid stimulatory effects $(2-3 \mathrm{~min})$ of ACTH and cyclic AMP on steroidogenesis (10).

We also sought to determine whether under conditions of graded dosage of ACTH there was any relationship between the quantity of endogenous cyclic AMP in adrenal glands and the level of ornithine decarboxylase activity. At each dose level the adrenals of one group of rats were removed $30 \mathrm{~min}$ after ACTH injection for cyclic AMP assay, and in a parallel group of rats, adrenals were removed $4 \mathrm{~h}$ after treatment for ornithine decarboxylase assay. A parallelism was observed between ACTH-induced increases in adrenal cyclic AMP and increases in ornithine decarboxylase activity (Fig. 7). Previous studies have shown that adrenal cyclic AMP levels of about $6 \mathrm{nmol} / \mathrm{g}$ tissue are associated with a maximal stimulation of steroidogene-

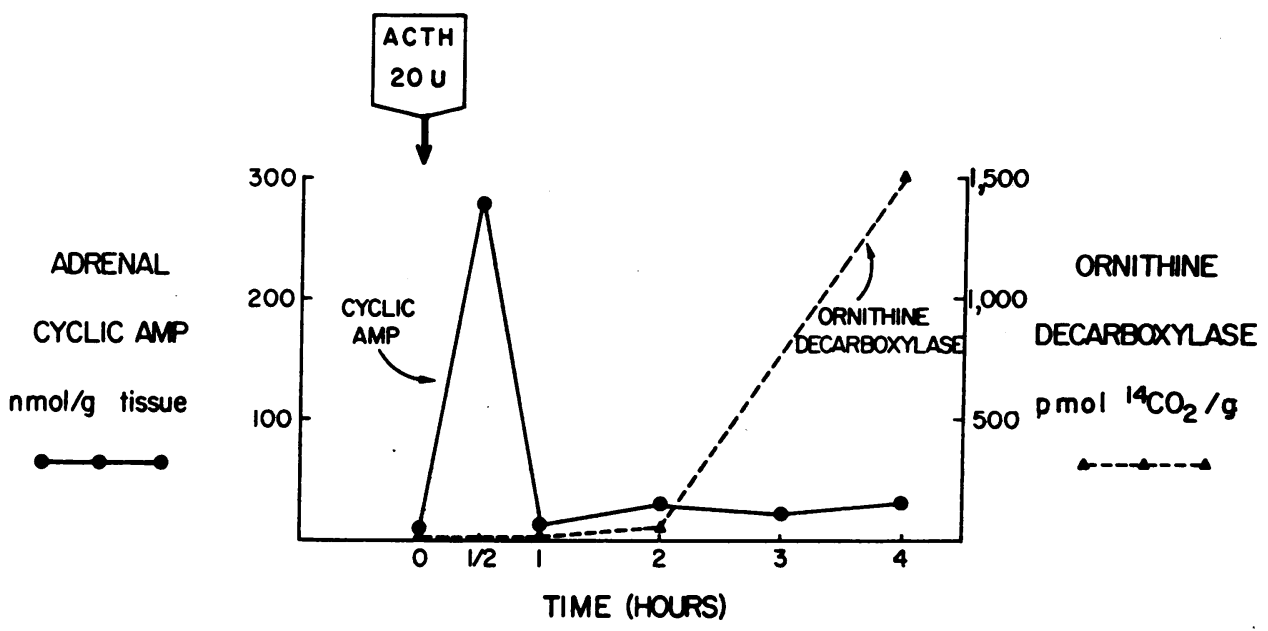

FIGURE 6 Time course of the effects of ACTH $20 \mathrm{U}$ subcutaneously on adrenal cyclic AMP content and ornithine decarboxylase activity in hypophysectomized rats. Adrenal cyclic AMP is expressed as nanomoles per gram tissue weight. The data for ornithine decarboxylase is the same as that for. Fig. 1, with activity expressed as picomoles liberated from ornithine per gram tissue. Each point both for the cyclic AMP and the ornithine decarboxylase data represents the mean of three observations. 


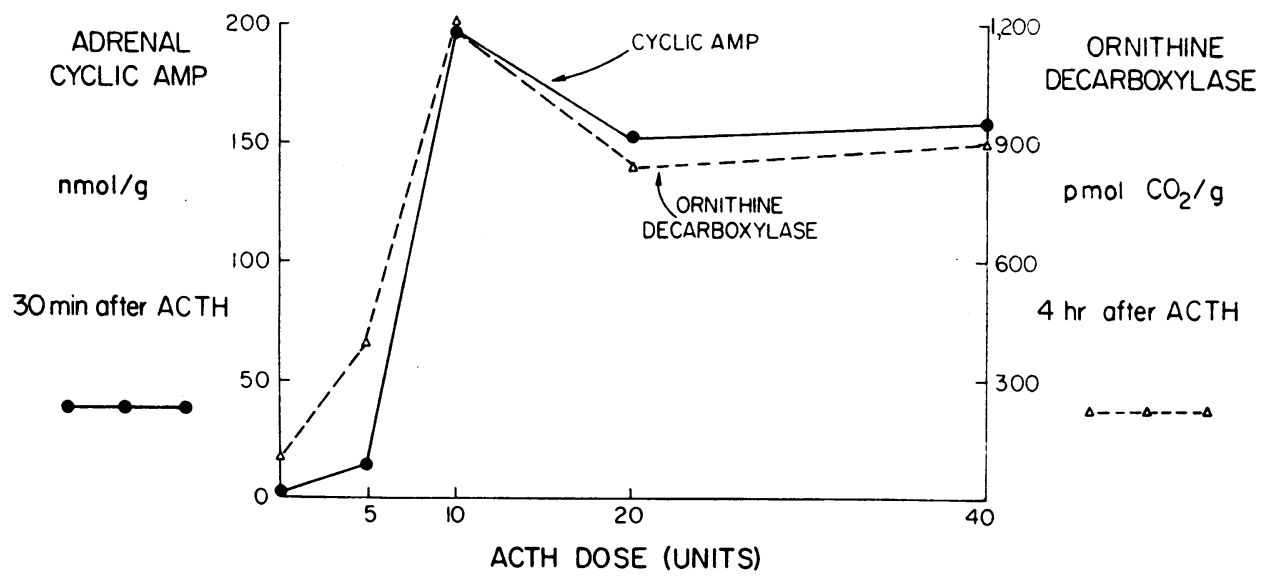

Figure 7 Effects of varying doses of subcutaneous ACTH on adrenal cyclic AMP and ornithine decarboxylase activity in hypophysectomized rats. Adrenals for cyclic AMP assay were removed $30 \mathrm{~min}$ after hormone treatment, and glands for ornithine decarboxylase assay were removed after $4 \mathrm{~h}$. The data for. ornithine decarboxylase activity has been shown previously in Fig. 2. Cyclic AMP concentrations are expressed as nanomoles per gram wet adrenal weight. Each point represents the mean of three observations.

sis (10). However it was established that ACTH is capable of increasing adrenal cyclic AMP to levels far in excess of this quantity. The present results show that the generation of such high levels of cyclic AMP (up to $200 \mathrm{nmol} / \mathrm{g}$ or more) is associated with parallel stimulation of ornithine decarboxylase activity (Fig. 7).

Effects of inhibitors of RNA and protein synthesis on adrenal ornithine decarboxylase activity. The administration of $1 \mathrm{mg}$ of actinomycin $\mathrm{D}$, a dose blocking adrenal RNA synthesis (18) given 10 min before AC$\mathrm{TH}$, attenuated the stimulation of ornithine decarboxyl-

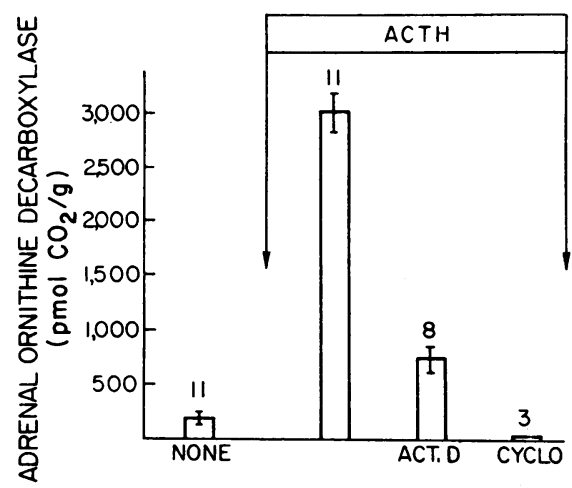

FIGURE 8 Effect of pretreatment with actinomycin D or cycloheximide on the ACTH stimulation of ornithine decarboxylase activity in hypophysectomized rats. The animals were given actinomycin $\mathrm{D}, 1 \mathrm{mg}$, or cycloheximide, $10 \mathrm{mg}$, intraperitoneally, followed $10 \mathrm{~min}$ later by a subcutaneous injection of $20 \mathrm{U}$ of ACTH. $4 \mathrm{~h}$ after the ACTH injection, adrenals were removed for ornithine decarboxylase assay. The values shown are means \pm SEM, with the numbers of observations shown above the bars. ase activity (Fig. 8). Similarly when $10 \mathrm{mg}$ of cycloheximide, a dose blocking adrenal protein synthesis (18) was given $10 \mathrm{~min}$ before $\mathrm{ACTH}$, the subsequent increase in ornithine decarboxylase activity was inhibited (Fig. 8).

Ornithine decarboxylase activity in an adrenocortical cancer. Since ornithine decarboxylase activity is usually increased in rapidly growing tissues, we examined the enzyme activity and its relationship to cyclic AMP levels in an adrenocortical cancer (11). Without exposure to $\mathrm{ACTH}$, the tumor maintained a high level of activity, 3,515 $\pm 654 \mathrm{pmol} \mathrm{CO}_{2}$ liberated/g tissue (mean \pm SEM, 15 observations). This occurred in spite of relatively constant cyclic AMP levels of $3.3 \pm 0.3$ $\mathrm{nmol} / \mathrm{g}$ (mean \pm SEM, 16 observations). On the other hand, normal adrenals develop comparable levels of ornithine decarboxylase activity after stimulation by large doses of ACTH that induce surges in tissue cyclic AMP to much higher levels (Fig. 7).

In light of the possibility that normal adrenal supernates might possess an inhibitor of ornithine decarboxylase activity (which is countered by high levels of cyclic AMP) or the possibility that tumor supernates might possess a stimulator (other than cyclic AMP) of ornithine decarboxylase activity, experiments were performed in which supernates from the two tissues were mixed. When equal quantities of supernates from the adrenal cancer and from hypophysectomized rat adrenals were mixed, the resulting enzyme activity of the mixture proved to be the average of the high tumor level and the low hypophysectomized adrenal level. Evidence for a tumor stimulator or an adrenal inhibitor of the enzyme activity was therefore not obtained. 
Effects of cyclic AMP on ornithine decarboxylase activity in vitro. Direct addition of cyclic AMP to the ornithine decarboxylase assay mixture, containing either adrenal or tumor supernate, resulted in no stimulation of enzyme activity (Table IV). In addition, quartered adrenals and adrenocortical cancer slices were preincubated for $2 \mathrm{~h}$ in vitro with or without exposure to cyclic AMP. The tissues were then homogenized, and the $20,000 \mathrm{~g}$ supernates were assayed for ornithine decarboxylase activity (Table V). Exposure of tumor to a $15 \mathrm{~min}$ pulse of cyclic AMP $(0.7 \mathrm{mM})$, at the start of the $2 \mathrm{~h}$ preincubation, resulted in higher enzyme activity than in untreated tumor slices. However enzyme activity in the tumor decayed during the $2 \mathrm{~h}$ preincubation (Table V), and even in the cyclic AMPtreated tissue, the activity was less than that of tumor assayed immediately after removal from the host. Cyclic AMP had no effect on quartered normal adrenals in vitro (Table V).

Effects of dibutyryl cyclic AMP on ornithine decarboxylase activity in the liver and kidneys. $\mathrm{Hy}$ pophysectomized rats were given $50 \mathrm{mg}$ dibutyryl cyclic AMP subcutaneously, and the liver and kidneys were removed $4 \mathrm{~h}$ later. Stimulation of ornithine decarboxylase in both organs was observed (Table II). However, since dibutyryl cyclic AMP also stimulates corticosterone production (17), we considered the possibility that these effects of the nucleotide were secondary to increased levels of adrenal steroids. Therefore, dibutyryl cyclic AMP was given to rats both hypophysectomized and adrenalectomized. No stimulation of liver or kidney ornithine decarboxylase was observed in animals so treated (Table II). Furthermore, hydrocortisone stimulated the enzyme activity in both tissues (Table II).

\section{DISCUSSION}

The results of the present experiments clearly indicate that ACTH markedly stimulates ornithine decarboxyl-

TABLE IV

Effect of Cyclic AMP Added Directly to Ornithine Decarboxylase Assay Employing 20,000 g Supernate either from Normal Rat Adrenals or a Rat Adrenocortical Cancer

\begin{tabular}{|c|c|c|}
\hline \multirow[b]{3}{*}{ Addition } & \multicolumn{2}{|c|}{ Ornithine decarboxylase activity } \\
\hline & \multicolumn{2}{|c|}{ Mean \pm SEM } \\
\hline & Adrenals & Tumor \\
\hline & \multicolumn{2}{|c|}{$\begin{array}{l}\text { pmol } \mathrm{CO}_{2} \text { liberated from } \\
\text { ornithine/g tissue }\end{array}$} \\
\hline $\begin{array}{l}\text { None } \\
\text { Cyclic AMP, } 1 \mathrm{mM}\end{array}$ & $\begin{array}{l}9 \pm 2(3)^{*} \\
10 \pm 3(3)\end{array}$ & $\begin{array}{l}2,757 \pm 193 \\
2,298 \pm 588\end{array}$ \\
\hline
\end{tabular}

* The number of observations is shown in parentheses.
TABLE V

Effect of Cyclic AMP In Vitro on Ornithine Decarboxylase Activity of Normal Rat Adrenals or Rat Adrenocortical Cancer Slices Incubated for $2 \mathrm{~h}$ at $37^{\circ} \mathrm{C}$ in Tissue Culture Medium (TC 199 with Hanks Salts)

\begin{tabular}{|c|c|c|}
\hline \multirow[b]{3}{*}{ Addition } & \multicolumn{2}{|c|}{ Ornithine decarboxylase activity } \\
\hline & \multicolumn{2}{|c|}{ Mean \pm SEM } \\
\hline & Adrenals & Tumor \\
\hline & \multicolumn{2}{|c|}{$\begin{array}{l}\text { pmol } \mathrm{CO}_{2} \text { liberated from } \\
\text { ornithine/g tissue }\end{array}$} \\
\hline $\begin{array}{l}\text { Untreated tissue, before } \\
\text { incubation }\end{array}$ & $43 \pm 8(3)^{*}$ & $2,582 \pm 75$ \\
\hline $\begin{array}{l}\text { Untreated tissue, after } \\
2 \mathrm{~h} \text { incubation }\end{array}$ & $22 \pm 13(3)$ & $303 \pm 39$ \\
\hline $\begin{array}{l}\text { Cyclic AMP, first } 15 \mathrm{~min} \\
\text { of } 2 \mathrm{~h} \text { incubation }\end{array}$ & $14 \pm 13(3)$ & $1,477 \pm 90$ \\
\hline
\end{tabular}

Cyclic AMP (final concentration $0.7 \mathrm{mM}$ ) was added for the first $15 \mathrm{~min}$ of the incubation. The medium was then changed to one free of cyclic AMP for the remainder of the $2 \mathrm{~h}$. Tissues were then homogenized and $20,000-g$ supernates used for enzyme assay.

* The number of observations is shown in parentheses.

ase activity in adrenal glands. This effect may be mediated by cyclic AMP. The role of cyclic AMP in the regulation of steroidogenesis was established in experiments showing that ACTH increases adrenal cyclic AMP levels, that the increase in cyclic AMP levels precedes stimulation of steroidogenesis, that a quantitative relationship exists between cyclic AMP levels and the rate of steroidogenesis, and that the nucleotide itself is capable of stimulating steroidogenesis (10). Similar lines of evidence implicate cyclic AMP in the regulation of ornithine decarboxylase in adrenal glands. Stimulation of ornithine decarboxylase by ACTH is preceded by increases in adrenal cyclic AMP. A quantitative relationship has been observed between adrenal cyclic AMP levels and ornithine decarboxylase activity. Finally, dibutyryl cyclic AMP strikingly increases adrenal ornithine decarboxylase activity in hypophysectomized rats in vivo.

Several interesting differences were observed in the relationship between adrenal cyclic AMP and steroidogenesis on the one hand and cyclic AMP and ornithine decarboxylase on the other. First, increases in adrenal cyclic AMP are followed within minutes by an increase in steroidogenesis (10), whereas stimulation of ornithine decarboxylase activity lags by several hours. Second, a dose of ACTH, which just maximally stimulates adrenal steroidogenesis, increases adrenal cyclic AMP levels to about $6 \mathrm{nmol} / \mathrm{g}$ (10). Larger doses of ACTH are capable of causing much greater increases 
in adrenal cyclic AMP, to as high as $200 \mathrm{nmol} / \mathrm{g}$ or more, without further increases in steroidogenesis. The capacity of ACTH to increase adrenal cyclic AMP to levels in excess of those capable of inducing maximal steroidogenesis has heretofore been without known biological significance. The results of the present experiments show that these high levels of adrenal cyclic $\mathrm{AMP}$, up to $200 \mathrm{nmol} / \mathrm{g}$, are associated with parallel increases in ornithine decarboxylase activity.

Cyclic AMP does not appear to be a general stimulator of ornithine decarboxylase in all tissues. Dibutyryl cyclic AMP stimulated enzyme activity in the liver and kidneys of hypophysectomized rats. However, it did not do so when the animals were also adrenalectomized suggesting an effect secondary to the stimulation of adrenal steroidogenesis. Hydrocortisone stimulated ornithine decarboxylase activity in the liver as has previously been described $(6,7)$ and also stimulated activity in the kidney.

The mechanism by which ACTH, and in turn cyclic AMP, stimulates adrenal ornithine decarboxylase activity is not certain from the present experiments. However, several lines of evidence suggest that the stimulation involves accumulation of the enzyme or a factor needed for its activity, rather than direct activation of preexisting enzyme by cyclic AMP. First, increases in adrenal ornithine decarboxylase activity follow peaks in tissue cyclic AMP by several hours. In fact, in ACTH-stimulated adrenals, cyclic AMP levels were on the decline by the time ornithine decarboxylase activity began to increase. Second, cyclic AMP had no stimulatory effect when added directly to the ornithine decarboxylase assay mixture. Since cyclic AMP-dependent protein kinases have been identified in mammalian tissues, (19-21) including adrenal glands (22, 23 ), we considered the possibility that cyclic AMP might stimulate ornithine decarboxylase by phosphorylation of the enzyme through this mechanism. However, preincubation of $20,000-g$ supernates of adrenal homogenates with cyclic AMP and other components that promote protein kinase activity $(22,23)$ resulted in no subsequent enhancement of ornithine decarboxylase activity in these supernates. ${ }^{2}$ It has recently been shown that cyclic AMP-dependent adrenal protein kinase can phosphorylate ribosomal proteins, and it has been suggested that the activity of ribosomes in protein synthesis may be modified through this mechanism (23). We can not exclude the possibility that cyclic AMP may increase adrenal ornithine decarboxylase formation through such a mechanism. Third, the stimulation of ornithine decarboxylase activity was blunted by actinomycin D and cycloheximide. However, the effects of

'Dobbins, C., and R. L. Ney. Unpublished observations. these agents may not have been due specifically to the inhibition of RNA and protein synthesis respectively (24). Definitive resolution of the question of whether or not increases in adrenal ornithine decarboxylase activity depend on increased synthesis of the enzyme must await development of means for quantitating the enzyme protein.

The measurement of ornithine decarboxylase activity and delineation of its relationship to cyclic AMP in an adrenocortical cancer was of interest for a number of reasons. Ornithine decarboxylase activity is increased in many rapidly growing tissues, including some tumors (5). However transformation of mammalian cells by oncogenic viruses has been associated with a reduction in cyclic AMP levels (25). In the rat adrenocortical cancer used in the present studies ornithine decarboxylase activity was' high, comparable to that of maximally stimulated adrenals. Cyclic AMP levels in the tumor averaged $3.3 \mathrm{nmol} / \mathrm{g}$ tissue. The values have been relatively stable at various times tested, without evidence for any abrupt rise in nucleotide levels. The tumor cyclic AMP levels are slightly higher than those of unstimulated adrenals (10) but are considerably below those seen in ACTH-stimulated adrenals that develop high ornithine decarboxylase activity. The results indicate that factors other than cyclic AMP are inducing high ornithine decarboxylase activity in the adrenocortical cancer.

The physiological role of ornithine decarboxylase activity in the regulation of adrenal growth remains to be determined. Activity of the enzyme and levels of the polyamines are increased in the regenerating liver (5), in embryonic tissues (5), and in certain tissues during hormone stimulation (6-8). ACTH stimulates the growth of adrenal glands, and dibutyryl cyclic AMP exerts an adrenal weight maintaining effect in hypophysectomized rats $(26,27)$. The present experiments show that ACTH and the nucleotide stimulate adrenal ornithine decarboxylase activity. However whether or not the activity of this enzyme is a rate-limiting step or necessary concomitant in the adrenal growth-promoting effect of ACTH has not been established.

Finally, the doses of ACTH that stimulated adrenal ornithine decarboxylase were large. Small intravenous pulses of ACTH in the range of $0.1-1.0 \mathrm{mU}$ stimulate adrenal steroidogenesis (10). It would appear that much larger doses of ACTH are needed to influence ornithine decarboxylase activity, and it therefore remains to be resolved whether this effect of the hormone is physiologically important. However it should be pointed out that in the present experiments ACTH was given subcutaneously, and the fraction of the hormone that reached the circulation was undetermined. Regardless of this question, the stimulation of adrenal 
steroidogenesis is associated with a low range of tissue cyclic AMP levels, while stimulation of ornithine decarboxylase activity follows the presence of much higher tissue levels of cyclic AMP.

Levine, Nicholson, and Orth have recently shown that large doses of growth hormone also stimulate adrenal ornithine decarboxylase activity (15). These doses of growth hormone do not elevate adrenal cyclic AMP levels. ${ }^{3}$ It is possible that ACTH and growth hormone stimulate the enzyme in different adrenal cell types. Alternatively, ACTH and growth hormone, and perhaps other unidentified pituitary factors (15), act in concert to regulate adrenal ornithine decarboxylase and growth, influencing the same adrenal cell population.

\section{ACKNOWLEDGMENTS}

This research was supported by U. S. Public Health Service grants CA-10408, AM-05574, AM-01022, and AM05330, and by grant BC-19A from the American Cancer Society.

\section{REFERENCES}

1. Tabor, H., and C. W. Tabor. 1964. Spermidine, spermine, and related amines. Pharmacol. Rev. 16: 245.

2. Kremzner, L. T. 1970. Polyamines. Fed. Proc. $29: 1560$.

3. Raina, A., and J. Janne. 1970. Polyamines and the accumulation of RNA in mammalian systems. Fed. Proc. 29: 1568 .

4. Snyder, S. H., and D. H. Russell. 1970. Polyamine synthesis in rapidly growing tissues. Fed. Proc. 29: 1575.

5. Russell, D., and S. H. Snyder. 1968. Amine synthesis in rapidly growing tissues: ornithine decarboxylase activity in regenerating rat liver, chick embryo, and various tumors. Proc. Natl. Acad. Sci. U. S. A. 60: 1420.

6. Panko, W. B., and F. T. Kenney. 1971. Hormonal stimulation of hepatic ornithine decarboxylase. Biochem. Biophys. Res. Commun. 43: 346.

7. Richman, R. A., L. E. Underwood, J. J. Van Wyk, and S. J. Voina. 1971. Synergistic effect of cortisol and growth hormone on hepatic ornithine decarboxylase activity. Proc. Soc. Exp. Biol. Med. 138: 880.

8. Williams-Ashman, H. G., A. E. Pegg, and D. H. Lockwood. 1969. Mechanisms and regulation of polyamine and putrescine biosynthesis in male genital glands and other tissues of mammals. Adv. Enzyme Regul. 7: 291.

9. Farese, R. V., and W. J. Reddy. 1963. Observation on the interrelations between adrenal proteins, RNA, and DNA during prolonged ACTH administration. Biochiom. Biophys. Acta. 76: 145.

10. Grahame-Smith, D. G., R. W. Butcher, R. L. Ney, and E. W. Sutherland. 1967. Adenosine 3',5'-monophosphate as the intracellular mediator of the action of adrenocorticotropic hormone on the adrenal cortex. J. Biol. Chem. 242: 5535 .

11. Ney, R. L., N. J. Hochella, D. G. Grahame-Smith, R. N. Dexter, and R. W. Butcher. 1969. Abnormal regulation of adenosine $3^{\prime}, 5^{\prime}$-monophosphate and cortico-

\footnotetext{
${ }^{3}$ Mahaffee, D., and R. L. Ney. Unpublished observations.
}

sterone formation in an adrenocortical carcinoma $J$. Clin. Invest. 48: 1733.

12. Raina, A. 1963. Studies on the determination of spermidine and spermine and their metabolism in the developing chick embryo. Acta Physiol. Scand. 60(Suppl. 218) : 1 .

13. Exss, R. E., H. D. Hill, and G. K. Summer. 1969. Computer analysis of amino acid chromatograms. $J$. Chromatogr. 42: 442.

14. Gilman, A. G. 1970. A protein binding assay for adenosine-3' :5'-cyclic monophosphate. Proc. Natl. Acad. Sci. U.S. A. $67: 305$.

15. Levine, J. H., W. E. Nicholson, and D. N. Orth. 1972. Evidence for an adrenal growth factor other than ACTH. Clin. Res. 20: 431.

16. Janne, J., and H. G. Williams-Ashman. 1971. On the purification of L-ornithine decarboxylase from rat prostate and effects of thiol compounds on the enzyme. $J$. Biol. Chem. 246: 1725.

17. Imura, H., S. Matsukura, H. Matsuyama, T. Setsuda, and T. Miyake. 1965. Adrenal steroidogenic effect of adenosine $3^{\prime}, 5^{\prime}$-monophosphate and its derivatives in vivo. Endocrinology. 76: 933.

18. Garren, L. D., R. L. Ney, and W. W. Davis. 1965. Studies on the role of protein synthesis in the regulation of corticosterone production by adrenocorticotropic hormone in vivo. Proc. Natl. Acad. Sci. U. S. A. 53: 1443.

19. Kuo, J. F., and P. Greengard. 1969. Cyclic nucleotidedependent protein kinases. IV. Widespread occurrence of adenosine $3^{\prime}, 5^{\prime}$-monophosphate-dependent protein kinase in various tissues and phyla of the animal kingdom. Proc. Natl. Acad. Sci. U. S. A. 64: 1349.

20. Walsh, D. A., J. P. Perkins, and E. G. Krebs. 1968. An adenosine $3^{\prime}, 5^{\prime}$-monophosphate-dependent protein kinase from rabbit skeletal muscle. J. Biol. Chem. 243: 3763.

21. Brostrom, C. O., J. D. Corbin, C. A. King, and E. G. Krebs. 1971. Interaction of the subunits of adenosine $3^{\prime}: 5^{\prime}$-cyclic monophosphate-dependent protein kinase of muscle. Proc. Natl. Acad. Sci. U. S. A. 68: 2444.

22. Gill, G. N., and L. D. Garren. 1971. Role of the receptor in the mechanism of action of adenosine $3^{\prime}: 5^{\prime}$ cyclic monophosphate. Proc. Natl. Acad. Sci. U. S. A. 68: 786 .

23. Walton, G. M., G. N. Gill, I. B. Abrass, and L. D. Garren. 1971. Phosphorylation of ribosome-associated protein by an adenosine $3^{\prime}: 5^{\prime}$-cyclic monophosphatedependent protein kinase: location of the microsomal receptor and protein kinase. Proc. Natl. Acad. Sci. U.S. A. $68: 880$.

24. Bransome, E. D., Jr. 1969. Actinomycin D in vivo: paradoxical and nonspecific effects on adrenal cortex. Endocrinology. 85: 1114.

25. Otten, J., J. Bader, G. S. Johnson, and I. Pastan. 1972. A mutation in a Rous sarcoma virus gene that controls adenosine $3^{\prime}, 5^{\prime}$-monophosphate levels and transformation. J. Biol. Chem. $247: 1632$.

26. Ney, R. L. 1969. Effects of dibutyryl cyclic AMP on adrenal growth and steroidogenic capacity. Endocrinology. $84: 168$.

27. Kvetňanský, R., G. P. Gewirtz, V. K. Weise, and I. J. Kopin. 1971. Effect of dibutyryl cyclic-AMP on adrenal catecholamine-synthesizing enzymes in repeatedly immobilized hypophysectomized rats. Endocrinology. 89: 50. 